City University of New York (CUNY) CUNY Academic Works

\title{
“Does It Have to be a Real Story?" A Social Semiotic Assessment of an Emergent Writer
}

Ted Kesler

CUNY Queens College

\section{How does access to this work benefit you? Let us know!}

More information about this work at: https://academicworks.cuny.edu/qc_pubs/399

Discover additional works at: https://academicworks.cuny.edu

This work is made publicly available by the City University of New York (CUNY).

Contact: AcademicWorks@cuny.edu 
“Does It Have to be a Real Story?” A Social Semiotic Assessment of an Emergent Writer

\author{
By Ted Kesler \\ Queens College, CUNY
}

Ted Kesler, Ed.D.

054H Powdermaker Hall

Department of Elementary and Early Childhood Education

65-30 Kissena Blvd.

Flushing, NY 11367

Queens College, City University of New York (CUNY), USA

718-997-5183 (w); 718-997-5325 (FAX)

tkesler@qc.cuny.edu

www.tedsclassroom.com

@ tedsclassroom

https://orcid.org/0000-0002-9417-2385

Keywords: writing assessment, parent-researcher, emergent writing, systemic functional linguistics, social semiotic perspective 


\title{
"Does It Have to be a Real Story?" A Social Semiotic Assessment of an Emergent Writer
}

\begin{abstract}
Standardized writing assessments based in linear progressions position teachers for deficit views of young children's emergent writing development. Consequently, the researcher videorecorded a writing assessment of his son, Daniel, at age 5 years, 4 months, as he composed a story across pages of a blank book, using an assortment of writing tools. Data sources included the transcription of the writing session and Daniel's final product. The researcher first used open coding then coding based in systemic functional linguistics. Based in ecological and social semiotic perspectives, the researcher shows how Daniel's writing development was expressed interpersonally, with the emerging text functioning as mediational tool. Findings show Daniel's emergent sense of self as a writer, the role of the adult facilitator, and the dynamics of interaction and dialectic of Daniel's internalization process. As formative assessment, next steps in instruction are suggested. The author discusses the necessities of closely observing and supporting young children's composing process and the imperative of a developmental assets perspective when assessing young children's writing, with implications for policy, teacher education, teaching, and research.
\end{abstract}

Keywords: writing assessment, parent-researcher, emergent writing, systemic functional linguistics, social semiotic perspective 
Ms. Shiavone (pseudonym) looked at me in frustration. "We're forced to use these rubrics, and all they do is show what many of my kids can't do!"

As a teacher educator and staff developer, I worry about the looks of despair on teachers' faces when they assess young children's writing that does not measure up to their assessment tools. These assessment measures position teachers to see deficits, or what some of their students are not yet able to do, and to not see assets, or what their students are already demonstrating. This deficit position is most apparent with my pre-service teachers, who do not yet have the experience to see beyond the rubrics. I want them to perceive the interpersonal, performative, and multimodal qualities that are inherent in assessing young children's writing to inform instruction, even as they sit side-by-side with one child for one writing event. This was my impetus to videorecord a Sunday morning writing session with my son, Daniel, at our kitchen table, in October of his kindergarten year. This video has proved to be one of the most useful professional development tools I have for the purpose of exploring how we assess the writing development of an emergent writer.

In this article, I intend to illuminate lessons learned through a close reading of this video, but also how these assessment lessons challenge common school-based assessment tools for emergent writers. I begin with theoretical framing of my analysis, a review of literature and discussion of my methodological approach. I then provide analysis of a transcript of this video footage. I conclude with insights about assessment and implications for policy, teacher education, teaching, and research.

\section{Theoretical Framework}

I began from the premise that young children's writing is emergent. Vygotsky's (1978) sociocultural theory of cognitive development provides the basis for the framework I use. Of 
particular value is his premise that the transaction and transformation of cultural knowledge such as literacy takes place on an interpersonal level between individuals before it is internalized on an intrapersonal level. Through extended opportunities for discussion and problem-solving in the context of shared activities, meaning and action are collaboratively negotiated and constructed, leading to creation of new knowledge, within a child's zone of proximal development, or "the distance between the actual developmental level as determined by independent problem solving and the level of potential development as determined through problem solving under adult guidance or in collaboration with more capable peers" (p. 86). For Vygotsky, a child's development occurs as a dialectic: through mediation of signs and tools within specific sociocultural contexts, the child both transforms those resources and is transformed in the process. Vygotsky emphasized dissonance in a child's internalization process: a complex dialectical process characterized by periodicity, unevenness in the development of different functions, metamorphosis or qualitative transformation of one form into another, intertwining of external and internal factors, and adaptive processes which overcome impediments that the child encounters. (p. 73).

To emphasize the interpersonal, I applied an ecological perspective. Children develop by engaging in processes of increasingly complex reciprocal interactions with persons, objects, and symbols in their immediate environment (Bronfenbrenner \& Morris, 1998). I use a developmental assets framework to implement and analyze an emergent writing task. Developmental assets are a set of interrelated experiences, relationships, skills and values that enhance child outcomes (Dickinson \& McCabe, 2001). For Vygotsky (1978), internalization involves an internal construction of an external interpersonal process which builds upon and is shaped by what the child can already do and understand. Developmental assets are interrelated, 
so having or acquiring one asset contributes to and reinforces the attainment of others (Sesma, Mannes, \& Scales, 2005). Therefore, assets that a young child expresses in writing development form the building-blocks for later school and life success (Pullen \& Justice, 2003).

My analysis was also driven by social semiotic theory. As children compose, they construct meaning using a repertoire of signs across modes and materials (Kabuto, 2014; Kress, 2003). Their process is driven by their interests. They take a productive, creative approach towards sign-making, that, in turn, leads to a transformation of their subjectivities. They strive for forms of expression that they believe are understandable to other participants. They also choose forms of representation that they see as most apt and plausible in the given context. In the book making episode of this study, for example, Daniel coordinated narration, writing, drawing, talk, movement, and sounds, in a mediated, non-arbitrary manner in the expression of meaning. Daniel's symbol weaving interacted with the materiality of paper, pen, markers, kitchen table, hard-backed chair, within the social context of this event. Daniel's uses of modes and materials constituted his process of semiosis, which generated his writing development. Consistent with systemic functional linguistics, the overall purpose of language and all other modes of expression is a semantic one, and each "text is a process of making meaning in context" (Halliday \& Matthiessen, 2014, p. 3). Daniel and I participated in "a multi-dimensional semiotic space - the environment of meanings to which language, other semiotic systems and social systems operate" (p. 34) to make sense of each other and his composing process.

\section{Review of the Literature}

Several writing assessment systems influenced the research and analysis in this study. In the area where I am - the northeast region, USA - rubrics developed by Calkins and colleagues (2015) are pervasive for diagnostic, formative, and summative assessments. Aligned with the 
Common Core State Standards, Calkins and colleagues developed writing continuums for narrative, opinion/argumentative, and informational writing for grades $\mathrm{K}$ through 8 . They advocate a feedback loop: making criteria for excellence in each genre clear to children, guiding students to recognize where they are in their skill level for each criterion, and supporting students to work towards goals for improvement. Therefore, the rubrics impose a linear hierarchy of predetermined qualities of excellence, based in national standards, for each genre. For example, for narrative writing in kindergarten: "The writer drew and wrote some details about what happened" (p. 357). This expectation puts some children at a deficit if they do not write words in their story. Teachers also apply these rubrics exclusively to students' finished products.

Calkins and colleagues (2015) specify administering an "on-demand" writing prompt prior to teaching each genre. Their emphasis is on independence as stated in the rationale: "When students are asked to produce their best work within an assigned time interval, working with absolutely no input from others, the resulting texts provide a clear demonstration of what students have learned to do independently" (p. 14). They also provide the same scripted prompt, grades $\mathrm{K}$ through 8 , that determines what counts as writing in each genre. For example, the prompt for narrative writing expects children to write a true, "Small Moment" story. The intention is to administer this on-demand assignment to the entire class, and then use the narrative rubric to score each child's writing. These directions further put some children in a deficit position, for example if they do not write a "Small Moment" story, or if the story is not about a real-life event. Moreover, the directions prevent interaction in the composing process and call for 45 minutes of writing time, far exceeding what young children might sustain.

In the field of emergent writing, Clay (1975/2013) derived 13 principles for observing early progress within a child's first six months of kindergarten, with a gradient of six behaviors 
in each of three areas: language level, message quality, and directional principles. However, Clay's principles and her rating scale attend only to a child's print, even though she shows many examples of children's drawings as part of their messages. As with Calkins and colleagues (2017), her study of young children's writing predominantly focuses on their final products, not their composing process.

Other scholars in emergent literacy ascribe stages of development to young children's writing (Graves, 1989; Temple, Nathan, \& Temple, 2012, Schickendanz, 1999). The First Steps resource (Department of Education Western Australia [DOEWA], 2013) connects developmental stages to assessment, teaching, and learning, so that teachers have clear instructional models to guide children in their development. These scholars and the First Steps resource express the reciprocity and spiraling of young children's writing development. For example, as they try on new writing skills, they might relinquish control of writing skills they have acquired, that, from an adult's perspective, may look like regression. However, developmental stages inevitably impose a linearity to evaluating young children's writing. For example, the First Steps resource (DOEWA, 2013) emphasizes, "students are considered to be in the phase where they exhibit all Key Indicators" (p. 14). Moreover, these frameworks continue to privilege print above drawing and other modes of expression.

Some scholars (Baghban, 2007; Harste, Woodward, and Burke, 1984) recognized children's writing development as multimodal. Ray and Glover (2008) used the term composing to emphasize young children's writing as more than getting words on the page. In order for assessment to guide instruction, they emphasized close observation and interaction with young children as they compose. They rejected a hierarchical model: "composition development is always multidimensional and simply refuses to follow lines of logical progression" (p. 58). Ray 
and Glover (2008) provided book-making time, when young children compose within the blank pages of a book. They developed a series of guiding questions along three dimensions: a child's understandings about texts; understandings about process; and understandings about what it means to be a writer. I followed their advice in administering the writing task for Daniel. I gave him a blank book, asked him to write a story, and observed and interacted with Daniel to gain clarity about his composing habits, process, and product, with no attention to pre-determined "lines of logical progression."

A few researchers have developed assessment tools to measure and describe emergent writers' change over time towards conventional writing and for comparison between children (Harmey, D’Agostino, \& Rodgers, 2017; Rowe \& Wilson, 2015). Both research groups conceptualized writing as a problem-solving activity in which the writer plans a message, generates it and self-monitors the entire process. They also valued child-adult interaction during the assessment process. Rowe and Wilson's (2015) Write Start! tool measures writing development for children ages 2 to 5 , in form, directional patterns, intentionality (assigning meaning to marks), and message, as they write a caption to a photo of themselves playing at school. This assessment uses a specific task protocol. It also only measures young children's written message as they progress towards conventional forms. In the limitations to this study, the researchers called for studies that address other important measures of young children's writing development, including children's metacognitive activity during writing, multimodal composing, genre-specific features of writing, understandings of the social functions of writing, and patterns of social participation with adults during the assessment process, as I do in this study.

Harmey et al. (2017) developed the Early Writing Observational Rubric (EWOR) that measures both changes over time in sources of information used and in problem-solving actions 
taken. EWOR is designed for young children who have had at least one year of formal schooling but are still emerging as conventional writers (i.e., end of kindergarten or beginning of first grade), one-on-one administration, and an open-ended writing task: the child is simply asked to write a message. They emphasized adult support during the assessment task for two reasons: (a) we gain information about the child's performance within his zone of proximal development; and (b) it better informs instruction, because the task is pitched at the level of what the child is learning how to do, rather than what the child has already learned. The results then provide practical implications for instruction. However, Harmey et al.'s (2017) assessment tool requires young children to encode their messages and attends entirely to the written message. In this study, I also attend to other semiotic dimensions of Daniel's composing.

\section{Methodology}

I present one writing event as a source of formative assessment with my son, Daniel, who was five years, four months old. Daniel was not in the habit of making books with his mom or me at home. Daniel also had few opportunities in kindergarten to experiment with writing tools and interact with friends in the process of making books. School writing was filling in the blank of a writing prompt, such as "This summer, I went to ", or "My favorite part of the story was __

One Sunday morning, we sat at our kitchen table, a plastic bucket of markers, pens, and pencils before us. I handed Daniel a blank book - two pieces of white paper folded width-wise and, with my support, I asked him to write a story. As he began, a thin purple marker lay above his book. My wife, Judy, videorecorded the process, and his sister, Korina, age seven, observed (and sometimes interjected). The research was naturalistic (Carey, 1980). I collected data in the natural setting of our kitchen, with Daniel in the presence of his family. In addition, I abandoned 
assumptions about what Daniel should be able to do as an early kindergarten writer, paying careful attention to observation and description, to preserve the complexity of the activity that Daniel and I engaged in.

\section{Researcher's Role}

In this study, I functioned as a parent-researcher (Kabuto, 2008). Kabuto discussed the complexity of this position with its inherent power differentials, and consequently how my two roles then positioned Daniel, as child informant, in our writing session. I address the complexity of our roles by showing how our session was co-constructed, with my concerted effort to tread lightly and allow Daniel to take the lead. My instructional moves are relevant to teachers who also have to negotiate equally complex power differentials whenever they meet one-on-one with children for literacy assessments. Kabuto also raised ethical issues. After all, as a parentresearcher, who did I have to ask for permission to study my son? He was too young to know nor did either of us yet realize all the ways I would share this work with pre- and in-service teachers. Cocks (2006) wrote, "Seeking assent requires the researcher to remain constantly vigilant to the responses of the child at all times; it is not something gained at the beginning of the research then put aside" (p. 257). This study, however, shows Daniel's genuine enjoyment of the performative nature of our writing session. Moreover, my university's Independent Review Board of ethics in research gave approval for this study. Finally, in order to maximize my ethical considerations towards Daniel as co-constructor of this study, I check in with him whenever I plan to use or report data from the video with an audience. For this paper, Daniel (at age 16) said, "it's about time," referring to a paper I wrote about Korina's writing (Kesler, 2012).

\section{Data Analysis}


Using microgenetic analysis, I transcribed the video recording. Table 1 shows an excerpt of this transcription, including relevant codes for analysis (see https://tinyurl.com/unzl66m for the complete transcript). Analysis included time intervals, transcription, comments, and codes. The transcription follows the structure of Daniel's book: Book Cover, First Opening, Second Opening, Third Opening, and Reading the Book. Speaking turns are numbered to facilitate analysis. Transcriptions include descriptions of Daniel's composing work, and all connected actions, including body movements, gestures, sound effects, and Daniel's visual focus or gaze. Time intervals give elapsed time for each continuous action before a shift in focus. They also provided a sense of real time of Daniel's composing process. The entire episode lasted 6 minutes and 39 seconds (6:39): 5:15 for composing, and 1:24 for re-reading his book. Comments in the transcript highlighted decisions I made and actions we took based on my role as facilitator of this session and from my intimate connection to Daniel. They provided first iterations of codes for emergent themes. I used an open coding process (Corbin \& Strauss, 2008) informed by an ecological perspective of writing development (Bronfenbrenner \& Morris, 1998). Through multiple readings, codes included: family relations, multimodal expressions, genre awareness, sense of audience, authorship, representation.

Table 1

Excerpt of Transcription

\begin{tabular}{lllll}
\hline TIME & TRANSCRIPTION & COMMENTS & $1^{\text {st }}$ CODES & $2^{\text {nd }}$ CODES \\
\hline 4:00- & He caps his pen in right & Whenever he caps his & ${ }^{49}$ Child: & ${ }^{52}$ textual \\
4:09 & hand. ${ }^{49}, 52$ & pen, he is showing & composing & metafunction \\
& 53. DADDY: "Daniel, & that he's finished. & process & ${ }^{31}$ ideational \\
& what are you making & I asked this question & ${ }^{\text {ee Adult: }}$ & metafunction \\
& now?"ee, 31 & for my own & probing & ${ }^{53}$ interpersonal \\
& 54. DANIEL: & clarification. & ${ }^{50}$ Child: & metafunction \\
& "Remember" [he & His glance at Judy & audience: & ${ }^{54}$ ideational, \\
& glances up at Judy ${ }^{50,}$ & may have been to & performative: & textual \\
& check that they were & attention & metafunctions \\
& on verso and points & still there recording & & \\
\hline
\end{tabular}




\begin{tabular}{|c|c|c|c|}
\hline 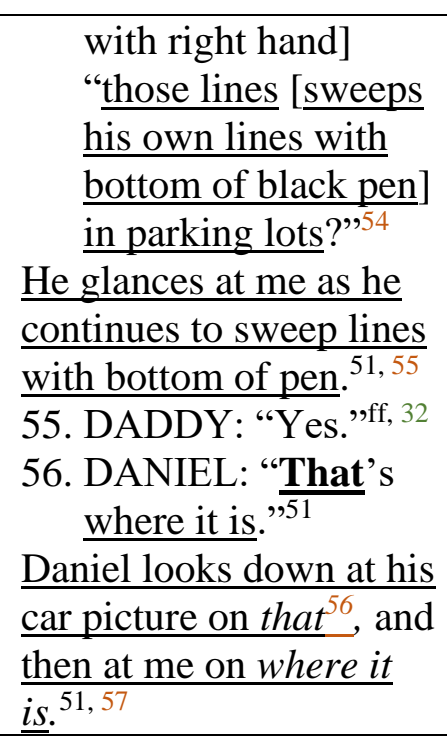 & $\begin{array}{l}\text { him. (He loved the } \\
\text { undivided attention.) } \\
\text { Daniel's sweeping } \\
\text { action again showed } \\
\text { composing as } \\
\text { multimodal. He was } \\
\text { demonstrating the } \\
\text { length of parking lot } \\
\text { lines with this } \\
\text { gesture. } \\
\text { When Daniel looked } \\
\text { at me, he was } \\
\text { checking if I } \\
\text { understood his } \\
\text { meaning. }\end{array}$ & $\begin{array}{l}{ }^{51} \text { Child: } \\
\text { Agency } \\
\text { ff Adult: } \\
\text { approval }\end{array}$ & $\begin{array}{l}{ }^{55} \text { interpersonal, } \\
\text { textual } \\
\text { metafunctions } \\
{ }^{32} \text { interpersonal } \\
\text { metafunction } \\
56 \text { textual } \\
\text { metafunction } \\
57 \text { interpersonal } \\
\text { metafunction }\end{array}$ \\
\hline
\end{tabular}

Notes. For $1^{\text {st }}$ Codes, Daniel's codes are numbers; Daddy's codes are letters. For $2^{\text {nd }}$ Codes, Daniel's codes are in gold; Daddy's codes are in green.

Transcription codes: bold indicates emphasis; underline indicates overlapping speech and actions; : indicates a stretched out word; :: indicates a longer stretched out word; $\uparrow \downarrow$ indicate rise or fall in pitch; [ ] indicates intervening actions or descriptors.

I then did a second layer of codes, adopting systemic functional linguistics (Halliday \& Matthiessen, 2014), based in social semiotics and useful in analysis of multimodal composition and visual design (Kress, 2003; Kress \& van Leeuwen, 2006). Halliday conceived three interconnected metafunctions of language: an ideational metafunction, or how the text represents the world outside and inside us; an interpersonal metafunction, or how the text is constructed to enact social interactions and relations; and a textual metafunction, or how the textual elements cohere to construct meaning. Consistent with multimodal methodology (see, for example, O'Halloran, 2008), I applied these three metafunctions to all modes of communication used as Daniel composed his story. I considered salience in his choice of color, what he centered or represented partially off frame, what noises and gestures he made as he composed, his gaze, and what actions he took. This system enabled me to see what Daniel was learning about composing as he participated in the composing process. 
The first layer of codes provided nuanced understanding of each of the meaning-based metafunctions that Daniel expressed in his composing process. First and second layers were coded for both child and adult, highlighting the interactional nature of our writing session. For the first, open coding, codes that applied to Daniel (or Korina) were indicated in numbers, and codes that applied to me (or Judy) were indicated in letters. (Korina and Judy were coded in blue font.) For coding of metafunctions, I numbered codes using gold (for Daniel) and green (for me) fonts. (Korina and Judy were coded in purple and red fonts, respectively.) Units of analysis were any continuous actions or grammatical level (sentences, clauses, phrases, words) that expressed distinct meaning for Daniel's composing process. Some units were double or even triple coded and were counted for each metafunction. For example, when Daniel explained his parking lines in his story, he also glanced at Judy to verify she was still videorecording, an interpersonal metafunction of audience. He also swept the lines with his pen, both to show where they were in his book (a textual metafunction) and to emphasize their meaning (an ideational metafunction), while he glanced up at me (an interpersonal metafunction) to verify my understanding of his authorial decisions. Multiple readings ensured consistency of coding. As with all integrated, multimodal texts, I teased apart each metafunction in my analysis to realize how they interact with and affect one another.

A second data source was Daniel's finished book (see Figures 1a through 1d), which, coupled with the transcription, provided a complete picture of his writing habits, process, and product. Through Daniel's deliberate actions in language, other modes of expression, and the composing of his book, his potential for meaning was changed. "That change to a person's inner resource, both through representation to the outer-world and through representation to their inner world, can be thought of as learning" (Kress \& Jewitt, 2003, p. 13). Below I present an analysis 
of Daniel's composing process to show his learning. I first provide an overview of the session, then unpack excerpts that illuminate important features of this session.

Figure 1a. Cover Page.

14
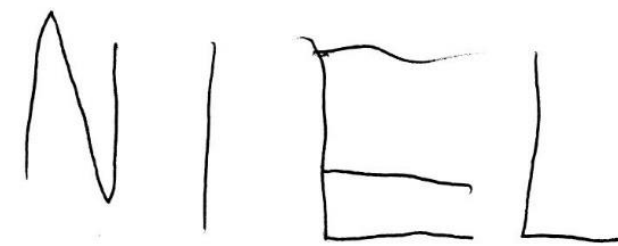

Gloss: Daniel 
Figure 1b. First opening.

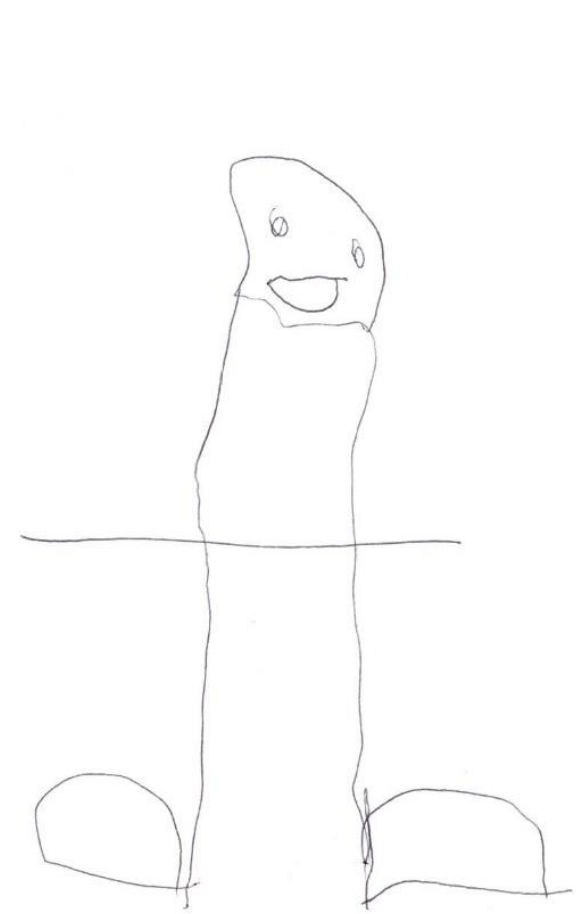

Gloss: First, I'm at home.



Then, I pick blueberries. 
Figure 1c. Second opening.


Gloss: Then, I go in a car.

Then, I park. 
Figure 1d. Third opening.

Gloss:

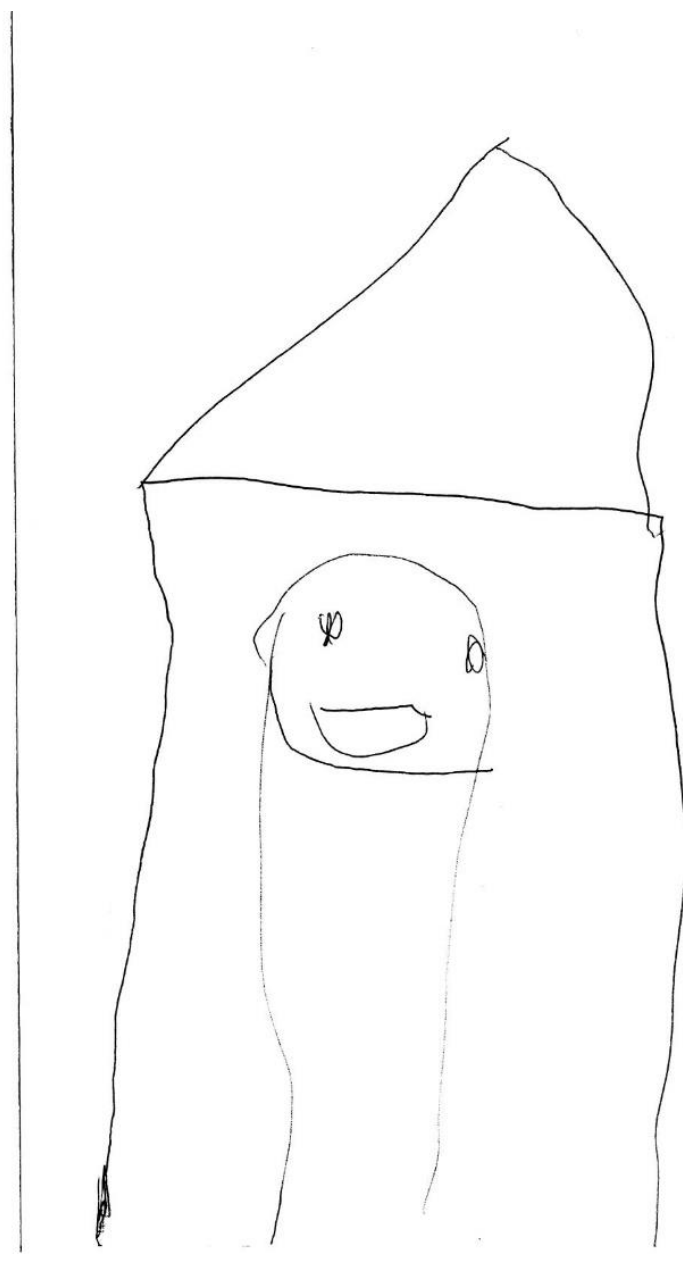

Next, I go home.

\section{Daniel's Composing Process}

\section{Overview}

Daniel took 5:15 to compose this story. We then took 1:24 to read and re-read his story, for a total of 6:39. Table 2 shows the distribution of codes for ideational, interpersonal, and textual metafunctions across our session for composing and reading his book, and combined totals. Percentages for each column are indicated in parentheses. The table shows that our session 
was interactional, but more than two thirds of the codes were generated by Daniel, indicating his agency. During composing, Daniel generated nearly $80 \%$ of textual codes, indicating his control of the textual process and product. Overall, $50 \%$ of Daniel's codes addressed the textual metafunction. During composing, while textual codes were most (44\%), Daniel expressed a balance of all three metafunctions (26\% ideational; $30 \%$ interpersonal). During reading, his attention went mostly to reproducing his textual product, and consequently nearly two thirds of Daniel's codes focused on the textual metafunction. My two ideational codes during reading were to verify that Daniel was done. Otherwise, during reading, I expressed a balance of interpersonal (10) and textual (11) codes. While $40 \%$ of my codes were interpersonal, as the adult facilitator, I had a balance of all three metafunctions overall (26\% ideational; $34 \%$ textual). Table 2

Summary of Codes

\begin{tabular}{lcccccc}
\hline & \multicolumn{2}{c}{ Composing } & \multicolumn{2}{c}{ Reading } & \multicolumn{2}{c}{ Total } \\
\hline & CHILD & ADULT & CHILD & ADULT & CHILD & ADULT \\
\hline Ideational Metafunction & $25(.26)^{\mathrm{a}}$ & $15(.36)$ & 0 & $2(.09)$ & $25(.19)$ & $17(.26)$ \\
Interpersonal Metafunction & $29(.30)$ & $16(.38)$ & $13(.35)$ & $10(.43)$ & $42(.31)$ & $26(.40)$ \\
Textual Metafunction & $42(.44)$ & $11(.26)$ & $24(.65)$ & $11(.48)$ & $66(.50)$ & $22(.34)$ \\
\hline Total & 96 & 42 & 37 & 23 & 133 & 65 \\
\hline
\end{tabular}

apercentage of total in each column.

Note. Code counts are for Daniel and Daddy only. All double and triple coded metafunctions were counted for each metafunction.

\section{Daniel Composes His Book}

Figures la through $1 d$ show Daniel's story that he titled "Daniel." The captions provide Daniel's reading of each page. His pages are out of order, an issue I will address later in this analysis. The figures show that his only use of colors was the bright green and purple of the blueberry bush. Otherwise, he used a black pen. When we began our session, Daniel had taken from the container both a black pen and a thin purple marker, but immediately wrote his name on the cover with the black pen. This was a textual metafunction that he likely learned in school: 
always write your name on your writing. The thin purple marker rested above his book. What was his intention for the purple marker? Did he already have going blueberry picking in mind or did the purple marker give him the idea? After writing his name on the cover, and opening the blank book to the first opening, Daniel and I had the following exchange:

(3) DADDY: "Okay" [and I tap the left-hand page] "so you can use markers if you want" [and I straighten the pages and the book in front of him] (because they shifted as Daniel oriented himself to these pages).

As I speak, Daniel almost caps the pen, then pulls his hands apart.

(4) DANIEL: "I'm gonna use just black!"

He points down with his right index finger for emphasis. He gazes at Judy, then at me.

(5) DADDY: "Fine. Why?"

When Daniel hears my approval, he looks down and begins drawing on the left-hand side of the page. Daniel draws his figure.

(6) DANIEL: "Because sometimes people just write with black."

(7) DADDY: "Okay."

(8) DANIEL: “That's what I'm gonna do."

Daniel continues drawing his figure.

(9) DADDY: “Okay."

In this exchange, I first made a textual gesture of tapping the left-hand side of the page (the verso), that implicitly indicated to Daniel where to begin writing his story. I then tried to encourage Daniel's use of all the writing utensils that were available, and not be confined only to the black pen. Daniel expressed emphatically his choice to use "just black" because of his awareness that sometimes people write just with black. But his authorial stance was also 
established interpersonally, indicated by Daniel's glance first at Judy, then at me, reading our faces for any signs of dis/approval. When he read our neutral faces and heard my approval ("fine"), he gained assurance with his stance, as indicated by our overlapping speech at Turns 7 and 8: he no longer needed to wait for my approval, establishing his authorial stance.

The following action then ensued:

Daniel glances up at the camera. Then, he continues drawing his figure.

(10) DANIEL: “Should I make a word like, 'Hi, I'm Daniel.'? Should I...?”

(11) DADDY: “Okay."

(12) KORINA: "You can do whatever you want" [with a hesitant voice].

Daniel's glance up at the camera was to make sure he was being recorded, showing that the performative quality of this event mattered to him. My overlap with Daniel's question was to encourage his agency for his own composing ideas. Korina said out loud what I was thinking. Her hesitant voice was because, as Daniel's older sister, she wanted to both express her authority, but also knew the interpersonal exchanges in this assessment event were between Daniel and me. We were establishing the pragmatics of this literary context. "Pragmatics is the system of language which joins language users, not only through convention but through negotiation and discretion" (Harste et al., 1984, p. 28). This exchange also shows the negotiation of personal convention and social convention. Perhaps from school or from one of our favorite read-aloud picture books, The Monster at the End of This Book (Stone \& Smollin, 2003), Daniel thought the main character should speak directly to the reader. "A personal convention is a decision reached because of a need experienced while participating in a language event" (Harste et al., 1984, p. 29). Somehow, in the interpersonal exchange, Daniel opted to continue drawing his main character without use of words. 
Daniel was also deliberate in his choice of green and purple markers. After drawing the figure ("me") on the verso of the first opening, he used the black pen to draw a circular shape for 13 seconds, then stopped, capped the pen, put it in the container, and grabbed instead a thin bright green marker. He then continued drawing the circular shape with the green marker for 16 seconds. I had tilted the container sideways to make the writing utensils more accessible. We had the following exchange:

(18) DADDY: "What are you making now?"

(19) DANIEL: “A bush.”

Daniel now digs in the container with his left hand.

(20) DANIEL: “And I'm gonna make blueberries and me..."

As he says blueberries, he glances at the purple marker and his left hand rolls over the

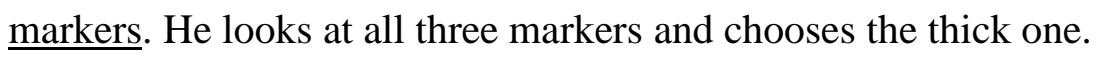

(21) DANIEL: “...picking them.”

Daniel uncaps the marker and starts coloring.

Here again, our interaction developed Daniel's ideas. At Turn 18, I asked an ideational question: "What are you making now?" which implies that his composing is about something meaningful. Daniel then articulated his idea to draw a blueberry bush and "me picking them," perhaps influenced by the choice of markers, or that it was fall and we had recently gone apple picking. He was now going to draw blueberries, and he deliberately passed over the thin purple marker in favor of the thick purple marker with an orange cap, showing awareness of the writing tool that was most apt for his purpose of drawing blueberries.

As Daniel drew the blueberries, we had the following exchange:

(22) DANIEL: "Daddy, does it need to be a real story?" 
Daniel continues coloring "blueberries," but at end of question, he looks directly at me.

(23) DADDY: "Are you making a real story or a pretend story?"

Daniel resumes coloring.

(24) DANIEL: "Pretend, because I'm picking blueberries."

At blueberries, Daniel again looks directly at me.

(25) DADDY: “Okay, fine.”

Daniel looks back at the recto and continues coloring.

Daniel expressed genre awareness, an ideational metafunction that was prompted by his textual process. He knew that stories could be real (i.e., realistic) or pretend (i.e., fictional), and since we had never gone blueberry picking and he never went apple picking alone, his story was pretend. But his genre awareness was established interpersonally, asking my permission, looking directly at me and waiting for my approval.

After drawing his blueberry bush, he capped the purple marker and again selected the black pen to draw a figure that was partially off the frame of the picture ("me picking them"). Daniel may have drawn the figure coming off the page to indicate movement towards the blueberry bush or simply because he had so little space on the right side of the blueberry bush on the recto. He made the sound "SHOOOO" to guide his hand as he drew a long, thin line up the page to squeeze in the figure. It's clear that the blueberry bush is what's centered, and its overall size and bright color give it most salience on the page. In the arc of his story, using bright green and purple markers to indicate the blueberry bush literally highlights that picking blueberries was the central event. Daniel made the same decision about use of color that some authors and illustrators of his familiar books do to create juxtaposition, focusing readers' attention to the most salient features of the story (see, for example, Wave, Lee, 2008). 
As Daniel drew his partial figure, we had the following exchange:

Daniel starts to uncap the pen.

(35) DADDY: "So, does this [I tap the verso] go with that [then the recto]?"

Daniel holds the black pen in left hand and the cap in right hand.

(36) DANIEL: "Nnnnnn..."

He glances at verso and points with his left index finger. He looks at me.

(37) DANIEL: "Yes, this is me in my house [now glances and points at blueberry bush drawing] and then [he glances at me, as he continues pointing] I drive" [glances at drawing, as he continues pointing, then at me on drive].

(38) DADDY: “Oh.”

(39) DANIEL: [glances back at picture] "...t::o...”

Points out picture with his left index finger. Puts down cap. Continues to hold pen in left hand.

(40) DADDY: "You drive?"

Daniel looks at me.

(41) DANIEL: "I drive to the blueberry picking."

On blueberry, Daniel simultaneously looks at me and pats the blueberry bush with his right hand.

(42) DADDY: “Okay.”

Daniel looks back at picture. Holds pen with right hand and begins drawing.

Daniel draws the figure.

(43) DANIEL: “And next I'm gonna draw my car parked."

As he draws the lines of the figure, he makes the sound, "SHOOOOOO." 
(44) DANIEL: "I'm not gonna make such a good car."

(45) DADDY: “Okay.”

I was unsure if Daniel had intended the figure of himself on the verso to go with the blueberry picking on the recto, consequently I asked my ideational question. At first, Daniel was tentative, voicing "Nnnnnn...," but by using his figure on the verso and my prompt for mediation, he seemed to solidify his narrative arc on the spot: that he drove from his house to blueberry picking. At Turn 26, I expressed my own ideational incredulity (“you drive?”): in his story, he created a fictional self that was old enough to drive. He stretched out or emphasized words that were key markers of the plot: drive, t::o, blueberry picking. Now, for the first time, Daniel expressed narrative intentions. "And next I'm gonna draw my car parked,” however, "I'm not gonna make such a good car."

On the verso of the second opening, Daniel drew his "not such a good car" in black pen. On the recto page, he then began drawing horizontal lines.

He caps his pen in right hand.

(53) DADDY: "Daniel, what are you making now?"

(54) DANIEL: " $\underline{\text { Remember }}$ he glances up at Judy, then left hand rests on verso and points with right hand] those lines [sweeps his own lines with bottom of black pen] in parking lots?"

He glances at me as he continues to sweep lines with bottom of pen.

(55) DADDY: "Yes.”

(56) DANIEL: "That's where it is."

Daniel looks down at his car picture on that, and then at me on where it is. 
(57) DANIEL: "See, this is me dri:ving he sweeps the pen in right hand across from car drawing to the parking lot lines] it, put it in park [sweeps pen across the two pages again], the:n do this."

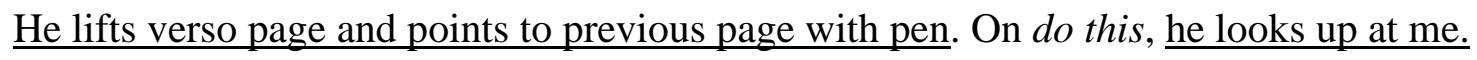
He slides this page of his book over to me. Daniel points at the car with the pen in his right hand, and he looks at his drawing. He puts the paper down and looks at his work. (58) DADDY: “Oh, then you went there?” Daniel smiles and realigns his pages. (59) DANIEL: "Yeah, so it's a little confu::sing $\downarrow . "$ Daniel glances at me, then back at his book, and slides top page away with left hand. In this exchange, Daniel established narrative sequence. This may have been Daniel's first time making a book, so he was developing narrative control across pages of a book. At Turn 53, I asked the same ideational question that I asked at Turn 18 that prompted Daniel's ensuing explanation. Daniel used the sweeping action of his right hand with the bottom of the pen to emphasize the horizontal linearity of the parking lot lines he drew. As he explained his drawing at Turn 54, his glance at Judy was to check that we were still being recorded, indicating the performative nature of Daniel's composing process. But his motions and his looks at me were to ensure that I was understanding his intentions: an interpersonal metafunction. Also noteworthy is Daniel's stretched out and emphasized words. At Turn 56, he emphasized that, to establish setting. At Turn 57, he emphasized and stretched out dri:ving, that established action. Motion was not apparent from his "not such a good car," and to ensure understanding, Daniel simultaneously made sweeping motions with the pen in his right hand across from car drawing to 
the parking lot lines. Then as he said "put it in park," he again embodied the motion from the verso to the recto page. Daniel then stretched out and emphasized the:n and the pictures in his book, concurrently turning back to the blueberry picking page, to establish story sequence. At Turn 59, Daniel expressed awareness of audience for the first time when he stated: "Yeah, so it's a little confu::sing $\downarrow$ " Confusing for whom? Not him. He understood how his book went. He was implying an audience of readers of his book. As a result of this "confusion," I then tried to intervene by offering a textual solution to the out-of-sequence pages. "Well, you know what we could do?" (Turn 64). But Daniel ignored me and continued on with the third opening, the ending, of his story. In the third opening, using the black pen, Daniel drew himself back home, again making sound effects that accompanied his drawing of lines for his house and figure.

\section{Daniel Reads His Book}

Daniel's reading of his book had a performative quality. For example, when I asked him to read his book the first time, he capped and put down his pen, put the book flat on the table and took the posture of a reader, as he might do at school. Moreover, I stopped Daniel at the start of his second reading: "Wait. Does your book have a name?" This was a textual question.

Daniel inhales.

(98) DANIEL: “Daniel $\downarrow . ”[$ His head goes down on second syllable.]

He looks over at my writing.

(99)DADDY: "Daniel," I repeat, and write it down.

When Daniel inhaled, he was considering what to call his book, and perhaps never considered before that his own authored books should have a title. When he looked at my writing, which he did at several intervals, he was impressed the occasion was important enough that I was writing down his words. 
In his first reading, Daniel began by stating again: "It's going to be a little confusing" (Turn 79), again showing his awareness of audience. His first reading was like a rehearsal, practicing how his book went:

(82) DANIEL: “The::n [he opens to 2nd opening] I went [he lifts this page to look at first opening verso and final recto. He puts the second opening down on top.] here." Daniel points with his left thumb at car on verso of second opening. (83) DADDY: “Uh, huh.”

(84) DANIEL: “And then [Daniel sweeps left hand to lines on recto] I parked down here."

He manipulated the pages to read his book in order, flipping from the verso of the first opening, to the second opening, back to the recto of the first opening, then to the recto of the third opening. In his reading, he emphasized story sequence and place words, establishing story structure: first, the::n, here, then, the::n, blueberries, then, home touching the pictures on each page for support.

For his second reading, when I transcribed what he said, Daniel was still gaining control of how his book went.

(101) DANIEL: "First, I'm at home."

Daniel points to first verso with left index finger but watches me write. (102) DADDY: “Uh, huh.”

(103) DANIEL: “The:n [his left index finger and gaze move to recto of $1^{\text {st }}$ opening], I'm picking [he glances at my writing] blu-"

(104) DANIEL: "The::n [he lifts and opens the page to $2^{\text {nd }}$ opening, then points to picture in verso with right index finger], I go in a car." 
His gaze now goes to recto.

\section{(105) DANIEL: "Then I park."}

He sweeps right index finger across to recto.

Perhaps because his focus went to my writing, Daniel stumbled over the correct sequence of his story, even during the second reading. He needed the mediation of the textual product. As in his

first reading, Daniel emphasized sequence, action, and place words, key structural components of narrative. By the recto of the second opening, he now established the correct sequence. However, even after finishing the reading, he continued looking through pages of the book, showing his tentativeness regarding the book's assemblage.

\section{Discussion}

So, what did assessing Daniel's writing show about his writing development? He made important design choices about what was most salient on each page, how to use color purposefully, and the choice of writing utensils to match his purposes. He used multimodal resources, such as embodiments, sound effects, and drawings to express his ideas. He developed a sense of coherence: that the events on each page fit together. Consequently, he developed an awareness of narrative structure, such as character, action, setting, story sequence, and an overall narrative arc. He realized that characters and events can be pretend, and that they can loosely be based on real life. Consequently, he gained an awareness of narrative genre, distinguishing pretend (i.e. fictional) from real (i.e. realistic) stories. He had an awareness of what authors do, including authorial stance and intentions. He had a sense of audience, and the need to accommodate his audience for understanding. He knew that books are read the same way each time. He knew that authors put their names on the cover page and realized that books have titles. 
The data showed how Daniel's writing development was constructed interpersonally (see Table 1). As several researchers advocate (Harmey et al., 2017; Harste et al., 1984; Ray \& Glover, 2008; Rowe \& Wilson, 2015), my support (a) provided insights about Daniel's performance within his zone of proximal development; and (b) better informed instruction, because the task was pitched at the level of what Daniel was learning how to do, rather than what he already learned. By conducting this assessment, if I were his classroom teacher, I would now know several possible teaching points, such as: teaching Daniel to plan and rehearse his story ahead of time; adding details to his drawings to show more about characters and setting and actions; analyzing how artists show motion in their illustrations, so he might apply these techniques; using more color choices and variety of writing utensils to express his meaning; composing a title that gives premonition of the story; working on encoding some words that he intends for his story. This is the point of formative assessment: to guide next steps in instruction.

What was the nature of my support in Daniel's zone of proximal development? The transcript shows how I guided with a light touch. I made a concerted effort to remain neutral whenever Daniel expressed his intentions, with responses such as “oh," "okay," "alright," "fine." I redirected Daniel's questions about his intentions. For example, when he asked if it needs to be a real story, I responded: “Are you making a real story or a pretend story?” I asked for clarifications: "You drive?" I asked questions that prompted ideational responses: "Daniel, what are you making now?” I prompted for elaboration. For example, after Daniel announced using “just black,” I responded, “Fine. Why?” which led to Daniel's establishing his authorial stance. I especially tread lightly with imposing adult expectations on Daniel's composing process. As noted in the findings, the one time I began a suggestion for resequencing Daniel's book, "Well, you know what we could do?" Daniel's overlapping action was starting his drawing on the third 
opening, literally pushing the folded middle page aside, effectively rejecting my suggestion. Daniel responded: "But this, huh, this was, this was really the first except I didn't have time so I didn't do this," and continued drawing. That was my signal to relinquish and again follow his lead. Overall, my support remained relevant to Daniel's own purposes (Vygotsky, 1978). It was spontaneous, arising mostly for the establishment and maintenance of intersubjective agreement between Daniel and me about how our writing session should be interpreted (Halliday, 1993). The data also showed Daniel's internalization process as he engaged in this activity. Daniel's internal construction of the process of story writing occurred in moments of dissonance between new sociocultural actions and interactions and what he could already do and understand (Vygotsky, 1978). He showed his dissonance multimodally as he negotiated if the pages of his book fit together (coherence), how to draw the figure of his adult self picking blueberries, how to show movement of driving and then parking his car, how to navigate his book, both during composing and reading it to an audience, for sequence. Daniel was developing control of his semiotic resources for the purpose of communication that "always reflects and tracks the values, structures, and meanings of the social and cultural world of the meaning-maker and of the sociocultural group in which they are" (Kress, 2003, p. 40). It was a big job for Daniel to compose a coherent story across pages of a book for perhaps the first time. While we might expect Daniel's steady progress towards more conventional forms of composing stories (Baghban, 2007; Rowe \& Wilson, 2015), we also should expect Daniel's variability in his progress: movement back and forth between more and less advanced strategies in his subsequent attempts to solve problems in writing (Clay, 1975; Harste, et al., 1984; Rowe \& Wilson, 2015; Vygotsky, 1978).

The data showed Daniel's emerging identity as an author that he expressed as he established his authorial stance and his performative actions and interactions. He established his 
authorial stance with his determination to use "just black," or establishing key elements of story, for example, that he was writing a pretend story and that he would be the only one driving to blueberry picking. He showed agency by rejecting my offer to "fix" the sequence of his story. He showed performative intentions with his awareness of Korina and of Judy with the video recorder, with the act of reading and re-reading his story as I transcribed. He relied on his deep interpersonal connections in our warm kitchen setting, and established an imagined audience of readers for whom his book might be "a little confu::sing $\downarrow$." Overall, in appropriating the resources of our sociocultural setting through participation in social action and interaction, Daniel both transformed those resources and was transformed in the process (Vygotsky, 1978).

\section{Implications}

Consistent with several researchers (Harmey et al., 2017; Harste et al., 1984; Ray \& Glover, 2008; Rowe \& Wilson, 2015), assessment of Daniel's writing development was best achieved interpersonally, as I sensitively interacted with Daniel and observed his composing process. This enabled me to perceive his multimodal writing assets, and only then imagine next steps in instruction, as formative assessment describes. If I had looked only at Daniel's writing product, I would have missed most of what he knew about writing at age 5. Rubrics, such as the assessment tools by Calkins and Colleagues (2015), would then give a deficit view of Daniel. Moreover, the "on-demand writing" directive to write a true Small Moment story would have prevented Daniel's imaginative fictional story with all the narrative discoveries he made. What was necessary for seeing Daniel's assets was the relational interactions between us, with prompts and exchanges that supported his composing process.

As stated in the introduction, my initial impetus for sharing the video of this composing session with pre- and in-service teachers of young children was to demonstrate the power of an 
asset perspective for formative assessment, even when sitting side-by-side with a child for one writing event. I place my pre-service teachers and provide professional development in urban poor public schools where early childhood writing assessment tools, imposed by policy makers, are now ubiquitous (e.g., Calkins, 2015). By focusing on children's products, these tools have potential deleterious outcomes of exposing deficits in young children's writing development, which harms their emerging literate identities (Yoon, 2015). Certainly, "a rush, or trend, toward the narrowing of assessment approaches to singular or product-driven conceptualizations of early composing should be avoided" (Quinn \& Bingham, 2019, p. 228). In actual classroom settings, teachers will have multiple opportunities for formative assessments. The First Steps resource (DOEWA, 2013) advocates a range of assessment methods to get a complete picture of children's writing development that fall broadly into three categories: focused observations, writing products, and conversations. Moreover, the authors emphasize, "any student behaviours (indicators) recorded have been displayed more than once and in a variety of contexts" (p. 14).

After administering “on demand” writing as diagnostic assessment, teachers like Ms. Shiavone in the opening vignette might identify those children who warrant another look, and schedule conference times to engage interpersonally with them as they compose to recognize assets in their composing process to build upon in instruction. Then, unlike Daniel's kindergarten experience, they should ensure "early writing as a social practice in which children generate ideas, refine their ideas by sharing them, and try to communicate these ideas through developmentally appropriate practices," provide "authentic writing opportunities in play," and "authentic opportunities to connect oral to written language through authoring and sharing texts" (Quinn \& Bingham, 2019, pp. 228-229). Australia’s First Steps writing resource (DOEWA, 2013) is one example of explicit instruction that links assessment to teaching and learning. This 
paper contributes to a growing body of work in assessing young children's writing development (e.g., Harmey et al., 2017; Ray \& Glover, 2008; Rowe \& Wilson, 2015) that builds upon their assets. Likewise, my approach was inherently dialogic, through naturalistic research, based in relationship and love. The results provide a necessary act for literacy research with aims to inform classroom practice for interpersonal pedagogy.

Note: Transcription codes: bold indicates emphasis; underline indicates overlapping speech and actions; : indicates a stretched out word; :: indicates a longer stretched out word; $\uparrow \downarrow$ indicate rise or fall in pitch; [ ] indicates intervening actions or descriptors.

Acknowledgements: The author thanks colleagues Sinéad Harmey, Bobbie Kabuto, Christopher Wagner, Ting Yuan, the anonymous reviewers, and editor Rita Elaine Silver, for all their helpful feedback. 


\section{References}

Baghban, M. (2007). Scribbles, labels, and stories: The role of drawing in the development of writing. Young Children, 62 (1), 20-26.

Bronfenbrenner, U. \& Morris, P. A. (1998). The ecology of developmental processes. In R. M. Lerner (Ed.) Handbook of child psychology, Vol. 1: Theoretical models of human development (5th ed.) (pp. 993-1028). New York, Wiley.

Calkins, L. (2015). Writing pathways: Performance assessments and learning progressions. Portsmouth, NH: Heinemann.

Carey, R. F. (1980). Empirical vs. naturalistic research? Reading Research Quarterly, 5, 412415.

Clay, M. M. (1975). What did I write? Beginning writing behavior. Portsmouth, NH: Heinemann.

Cocks, A. (2006). The ethical maze: Finding an inclusive path towards gaining children's agreement to research participation. Childhood, 13 (2), 247-266.

Corbin, J., \& Strauss, A. (2008). Basics of qualitative research (3rd ed.). Los Angeles, CA: SAGE.

Department of Education Western Australia [DOEWA] (2013). First Steps Writing Map of Development. Western Australia: Author. Retrieved Januay 8, 2020 from: http://det.wa.edu.au/stepsresources/detcms/navigation/first-steps-literacy/.

Dickinson, D. K. \& McCabe, A. (2001) Bringing it all together: the multiple origins, skills, and environmental support of early literacy. Learning Disabilities Research and Practice, 16, $182-202$.

Graves, D. H. 1989. "Writing: Teachers and Children at Work." In D. S. Strickland and L. M. 
Morrow (Eds.), Emerging Literacy: Young Children Learn to Read and Write. Newark. DE: International Reading Association.

Halliday, M. A. K. (1993). Towards a language-based theory of learning. Linguistics and Education, 5(2), 93-116.

Halliday, M. A. K. \& Matthiessen, C. M. I. M. (2014). Halliday's introduction to functional grammar ( $4^{\text {th }}$ ed.). London: Arnold.

Harmey, S., D’Agostino, J., \& Rodgers, E. (2017). Developing an observational rubric of writing: Preliminary reliability and validity evidence. Journal of Early Childhood Literacy.

DOI: $10.1177 / 1468798417724862$

Harste, J. C., Woodward, V. A., \& Burke, C. L. (1984). Language stories \& literacy lessons. Portsmouth, NH: Heinemann.

Kabuto, B. (2008). Parent-research as a process of inquiry: an ethnographic perspective. Ethnography and Education, 3 (2), 177-194.

Kabuto, B. (2014). What do those marks really mean? A semiotic perspective to writing in a bilingual context. In B. Kabuto \& P. Martens (Eds.), Linking families, learning, and schooling (pp. 19-33). New York: Routledge.

Kesler, T. (2012). Writing with voice. The Reading Teacher, 66 (1), 25-29.

DOI: 10.1002/TRTR.01088.

Kress, G., \& Jewitt, C. (2003). Introduction. In C. Jewitt \& G. Kress (Eds.), Multimodal literacy (pp. 1-18). Peter Lang: New York.

Kress, G. (2003). Literacy in the new media age. New York: Routledge.

Kress, G., \& van Leeuwen, T. (2006). Reading images: The grammar of visual design (2nd ed.). 
London: Routledge.

Lee, S. (2008). Wave. San Francisco, CA: Chronicle Books.

O’Halloran, K. L. (2008). Systemic functional-multimodal discourse analysis (SF-MDA): constructing ideational meaning using language and visual imagery. Visual Communication, 7, 444-475.

Pullen, P. C. \& Justice, L. M. (2003) Enhancing phonological awareness, print awareness, and oral language skills in preschool children. Intervention in School and Clinic, 39, 87-98.

Quinn, M. F., \& Bingham, G. E. (2019). The nature and measurement of children's early composing. Reading Research Quarterly, 54 (2), 213-235.

Ray, K. W., \& Glover, M. (2008). Already ready: Nurturing writers in preschool and kindgergarten. Portsmouth, NH: Heinemann.

Rowe, D. W., \& Wilson, S. J. (2015). The development of a descriptive measure of early childhood writing: Results from the Write Start! Writing Assessment. Journal of Literacy Research, 47 (2), 245-292.

Schickendanz, J. A. (1999). Much more than the ABCs: The early stages of reading and writing. Washington, D.C.: National Association for the Education of Young Children.

Sesma, A., Mannes, M. \& Scales, P. C. (2005) Positive adaptation, resilience, and the developmental asset framework. In S. Goldstein \& R. B. Brooks (Eds) Handbook of resilience in children (pp. 281-296). New York: Kluwer Academic Publishers/Plenum.

Stone, J., \& Smollin, M. (2003). The Monster at the End of This Book. New York: Random House.

Temple, C., Nathan, R., Temple, C. (2012). The Beginnings of Writing (4th ed.). Needham Heights, MA: Pearson. 
Vygotsky, L. S. (1978). Mind in society: The development of higher psychological processes. Cambridge, MA: Harvard University Press.

Yoon, H. S. (2015). Assessing children in kindergarten: The narrowing of language, culture and identity in the testing era. Journal of Early Childhood Literacy, 15 (3), 364-393. 